РЕЦЕНЗИИ. НАУЧНЫЕ ФОРУМЫ REVIEWS. DISCUSSION FORUMS

РЕЦЕНЗИЯ НА БИОБИБЛИОГРАФИЧЕСКИЙ СЛОВАРЬ «ДОКТОРА ЮРИДИЧЕСКИХ НАУК, ПРОФЕССОРА ПРЕПОДАВАТЕЛИ И ВЫПУСКНИКИ ИРКУТСКОГО ГОСУДАРСТВЕННОГО УНИВЕРСИТЕТА». ФГБОУ ВО «ИГУ», ЮРИД. ИН-Т / ПОД РЕД. В. Н. КАЗАРИНА. ИРКУТСК: ИЗД-ВО ИГУ, 2018. 252 с.

\author{
В.М. Сырых ${ }^{1}$
}

Российский государственный университет правосудия 117418, Москва, Россия, ул. Новочеремушкинская, д. 69

Посвящена биобиблиографическому словарю «Доктора юридических наук, профессора - преподаватели и выпускники Иркутского государственного университета». Рецензент указывает, что в книге впервые в истории юридической науки России собраны материалы о профессорах, докторах права, доцентах, основателях юридического факультета Иркутского государственного университета (1918 г.). Составителями исследованы материалы архивных документов, журнальные и газетные статьи тех лет. Кроме того, авторы собрали данные о докторах наук, профессорах, выпускниках юридического факультета ИГУ, их вкладе в развитие отечественной правовой науки.

Ключевые слова: Иркутский государственный университет, доктора юридических наук России, история иркутского университета, юридический факультет ИГУ

В октябре 2018 г. свой столетний юбилей отметил Иркутский государственный университет, второй университет в Сибири и первый к востоку от Томска. К этому событию был издан Биобиблиографический словарь, посвя-

1 (C) Сырых B.M., 2019.

This work is licensed under a Creative Commons Attribution 4.0 International License https://creativecommons.org/licenses/by/4.0 
щенный докторам юридических наук, профессорам — выпускникам и преподавателям старейшего университета России.

В словаре впервые представлены 73 персоналии, чья научно-педагогическая судьба так или иначе была связана с ИГУ. Из них 4 - Заслуженных деятеля науки РСФСР и РФ (А.Т. Боннер, В. Н. Дурденевский, А.Ф. Клейнман, Н.П. Фарберов), Заслуженный деятель высшей школы РФ (Р.Л. Хачатуров), 5 государственных советников юстиции 1-3 класса и генералов, 21 Заслуженный юрист РСФСР и РФ. Таким послужным списком может гордиться далеко не каждый региональный университет.

Иркутский государственный университет возник в годы гражданской войны в составе двух факультетов: юридического и историко-филологического на территории, контролируемой вначале Омским демократическим правительством, а затем правительством адмирала А.В. Колчака. Это обстоятельство и предопределило первые составы профессоров и преподавателей молодого университета, продолжившего традиции российского высшего гуманитарного образования. В книге собраны материалы о профессорах, докторах права, доцентах ведущих российских университетов, «отцов-основателей» учрежденного в 1918 г. Университета, в составе которого был юридический факультет (М.М. Агарков, В.П. Доманжо, Г.Ю. Маннс, С.П. Покровский) до наших современников. Такого соединения в одном издании персоналий, докторов юридических наук, профессоров, чья научно-педагогическая деятельность так или иначе связана с Иркутским университетом, ранее не было.

Книга в известном смысле продолжает традицию словарей биографий, в том числе Энциклопедического словаря «Видные ученые-юристы России (вторая половина XX в.)» и «Правовая наука и юридическая идеология России» под ред. В.М. Сырых, Краткого биографического словаря «Русские цивилисты: середина XVIII — начало XX в.» под ред. О.Ю. Шилохвоста, биографических публикаций В.А. Томсинова, Библиографического справочника в восьми томах «Профессора и доктора наук Саратовской области. 1909-1999» под ред. Д.И. Трубецкова, других исследователей.

Словарю предшествует обстоятельная статья, в которой прослежен исторический путь формирования иркутской правовой школы, становления и развития научных исследований и роль профессоров в подготовке кадров, прежде всего для правоохранительной и судебной системы России и Монголии. Многие судьи и работники правоохранительных систем Сибири и Монголии получили высшее юридическое образование в Иркутском университете и гордятся этим.

Составителями использованы материалы упомянутых выше биографических изданий, журнальных и газетных статей, архивных документов, многие из которых введены в научный оборот впервые. Неоценимую помощь в подготовке Словаря оказал выпускник юридического факультета ИГУ, ныне доктор юридических наук, профессор Н.А. Власенко. Заметим, поскольку Словарь охватывает достаточно продолжительный период, около ста лет, для облегчения 
восприятия текстов автором в приложении приведены прежние и современные наименования высших учебных заведений.

Все биографические справки построены по единому принципу: изложены основные биографические данные (при отсутствии точных сведений поставлен знак вопроса), этапы научно-педагогической деятельности, награды, отражены научные интересы, указаны основные труды (до 10 и более), наиболее значимые публикации о персоналиях (до 5, если позволяла источниковая база). Подавляющее большинство биографий сопровождено фотографиями, в том числе редкими, имеющимися в фондах Государственного архива Иркутской области или ведомственного архива Иркутского университета. Некоторые фотографии были предоставлены родственниками профессоров, когда-то работавших в Иркутском университете.

В отношении первых профессоров, чья научно-педагогическая деятельность начинались до радикальных перемен 1917 года, в книге указаны ученые звания того периода — «экстраординарный», «ординарный профессор». Кроме того, дана информация об обучении в магистратурах, научных зарубежных командировках, предусмотренных существовавшей тогда системой подготовки к профессорскому званию. Информация о служебной деятельности профессоров представлена в соответствии с имеющимися проверенными источниковыми данными.

При составлении Словаря коллектив столкнулся со многими трудностями. Прежде всего, это касается первых профессоров-юристов университета, о которых сохранились немногие архивные документы. Настоящей творческой удачей было отыскать в архивах личные дела некоторых, но далеко не всех, преподавателей. Однако и эти документы подчас немногословны: приказ о зачислении на должность, приказ об отчислении с должности. Учитывая условия Гражданской войны, а также зачистки некоторых документов периода «Белой Сибири» после установления здесь ревкомовской, а позднее большевистской власти, многие документы представлены весьма скупо. Поэтому восстанавливались основные биографические данные посредством привлечения других архивных документов (протоколы заседаний правления и Ученого совета университета, отчеты подразделений об основных видах работы, выполнение преподавателями учебных планов и др.). Достаточно сложно было проследить дальнейшую судьбу некоторых преподавателей. Одних из них ждала чужбина (А.М. Горовцев — Франция, В.А. Рязановский — Китай, затем США), другие продолжили свою деятельность в других высших учебных заведениях (Москва, Саратов, Свердловск). К сожалению, репрессии конца 1930-х гг. прекратили жизнь многих первых профессоров юридического факультета ИГУ: И.А. Антропова, Г.Ю. Маннса, В.Н. Охоцимского, Ю.М. Позана и др.

Проводимые в 1930-е годы реформы в области высшего образования были направлены на выделение из состава сложившихся университетов отдельных профильных институтов. Так, в 1931 году был создан Иркутский институт советского права, переехавший в 1934 году в город Свердловск (подробнее см.: 
«Свердловский юридический институт. 1931-1981». Под ред. Д.Д. Остапенко. M., 1981).

Изучены сохранившиеся личные дела (с различной степенью информативности) тех, кто воссоздавал высшее юридическое образование в Восточной Сибири с конца 1940-х: Н.П. Фарберова, В.А. Пертцика, З.Г. Крыловой, В.Д. Арсеньева. К сожалению, пожар 1989 г. в архиве Иркутского университета уничтожил некоторые архивные документы, а сохранившиеся дела этого периода стали нечитабельными. В этой ситуации восстановление биографических данных происходило через поиск других документов: отчетов о работе кафедр, приказов об избрании на должность, справок о представлении к ученому званию и других. Данные о выпускниках ИГУ, современниках, ставших докторами юридических наук, представлены на основании анкеты, составленной сподвижником издания Виктором Николаевичем Казариным. Эта информация подверглась самой минимальной редакторской обработке.

Библиография трудов профессоров составлена с учетом тех работ, которые вышли в период их работы на юридическом факультете университета. Это расширяет наши знания о научной деятельности в эти годы. При этом указаны и основные работы более позднего периода. Относительно библиографии научных трудов выпускников, то она составлена в большинстве случаев ими по собственному выбору. Необходимо отметить достойное полиграфическое оформление юбилейного издания.

Вместе с тем содержание Словаря было бы более информативным, если в нем нашли отражение не только научные интересы персоналий прошлого и настоящего, но и развернуто отмечен их вклад в развитие соответствующей отрасли юридической науки. Иначе говоря, в Словаре отсутствует очень важное информация о достижениях того или иного исследователя в сфере конкретной юридической науки.

В целом Биобиблиографический словарь существенно расширил и конкретизировал знания научного сообщества о юристах-профессорах России XX начала XXI вв. Можно пожелать продолжить эту работу с учетом возможных дополнений и уточнений в будущем.

\section{Об авторе:}

Сырых Владимир Михайлович - доктор юридических наук, профессор, главный научный сотрудник Центра исследования проблем правосудия, Российский государственный университет правосудия, Заслуженный деятель науки РФ

SPIN: 2073-4106

e-mail:2707xyz@mail.ru

\section{Для цитирования:}

Cырых B.M. Рецензия на биобиблиографический словарь «Доктора юридических наук, профессора - преподаватели и выпускники Иркутского государственного университета». ФГБОУ ВО «ИГУ», Юрид. ин-т / Под ред. В. Н. Казарина. Иркутск: Изд-во ИГУ, 
2018. - 252 с. // Вестник Российского университета дружбы народов. Серия: Юридические науки. 2019. Т. 23 № 4. С. 622-626. DOI: 10.22363/2313-2337-2019-23-4-622-626.

Дата поступления в редакциюю: 10 сентября 2019 г.

Дата принятия к печати: 15 октября 2019 г.

Review

\title{
REVIEW OF THE BIO-BIBLIOGRAPHIC DICTIONARY "DOCTORS OF LAW, PROFESSORS - TEACHERS AND GRADUATES OF IRKUTSK STATE UNIVERSITY". "ISU", LAW. IN-T / ED. V.N. KAZARINA. IRKUTSK: ISU PUBLISHING HOUSE, 2018. 252 p.
}

\author{
Vladimir M. Syrykh \\ Russian State University of Justice \\ 69, Novocheremushkinskaya str., 117418, Moscow, Russia
}

\begin{abstract}
Dedicated to the bio-bibliographic dictionary "Doctors of Law, Professors - Teachers and Graduates of Irkutsk State University". The reviewer indicates that the book for the first time in the history of Russian legal science contains materials about professors, doctors of law, associate professors, founders of the law faculty of Irkutsk State University (1918). The compilers studied materials of archival documents, magazine and newspaper articles of those years. In addition, the authors collected data on doctors of sciences, professors, graduates of the Faculty of Law of ISU, their contribution to the development of domestic legal science.

Key words: Irkutsk State University, doctors of legal sciences in Russia, history of the Irkutsk University, faculty of law, ISU
\end{abstract}

\section{About author:}

Vladimir M. Syrykh - Doctor of Legal Sciences, Professor, Chief Researcher of the Center for the Study of Justice Problems of the Russian State University of Justice, Honored Scientist of the Russian Federation

SPIN: 2073-4106

e-mail: 2707xyz@mail.ru

\section{For citation:}

Syrykh, V.M. Review of the bio-bibliographic dictionary "Doctors of Law, Professors Teachers and Graduates of Irkutsk State University". "ISU”, Law. in-t / Ed. V.N. Kazarina. Irkutsk: ISU Publishing House, 2018. 252 p. RUDN Journal of Law. 23 (4), pp. 622-626. DOI: 10.22363/2313-23372019-23-4-622-626.

Article received September 10, 2019

Article accepted October 15, 2019 